\title{
FIRST RECORD OF THE SCHINDLER'S FISH, SCHINDLERIA PRAEMATURA (ACTINOPTERYGII: PERCIFORMES: SCHINDLERIIDAE), FROM THE RED SEA
}

\author{
Mohamed A. ABU EL-REGAL ${ }^{1,2 *}$ and Takeshi $\mathrm{KON}^{3}$ \\ ${ }^{1}$ Marine Biology Department, Faculty of Marine Sciences, King Abdulaziz University, Jeddah, Saudi Arabia \\ ${ }^{2}$ Marine Science Department, faculty of Science, Port Said University, Egypt \\ ${ }^{3}$ University of the Ryukyus, Japan
}

\begin{abstract}
Abu El-Regal M., Kon T. 2019. First record of the Schindler's fish, Schindleria praematura (Actinopterygii: Perciformes: Gobioidei: Schindleriidae), from the Red Sea. Acta Ichthyol. Piscat. 49 (1): 75-78.

Abstract. The paedomorphic gobioids of the family Schindleriidae, collectively known as infantfishes, live in shallow waters of the Indo-West Pacific. The extremely paedomorphic genus Schindleria is a taxon representing fishes of very small dimensions. Eight specimens of male and female Schindleria praematura (Schindler, 1930) were collected by a light trap in September 2015, from a reef lagoon in Magawish Island in Hurghada on the Egyptian coast of the northern Red Sea. This is the first record of the species in the Red Sea and adds to the high number of species of the family Schindleriidae in the area.
\end{abstract}

Keywords: Schindleria praematura, Red Sea, first record, paedomorphic fish, distribution

\section{INTRODUCTION}

The paedomorphic gobioids of the family Schindleriidae, collectively known as infantfishes, are an unusual group of small, planktonic fishes living in shallow waters of the Indo-West Pacific, usually close to coral reefs (Johnson and Brothers 1983, Watson and Walker 2004). The extremely paedomorphic genus Schindleria (Gobioidei, Schindleriidae) includes one of the shortest (8 $\mathrm{mm}$ long), lightest (2 $\mathrm{mg}$ ), and youngest reproducing (23 days, 10 generations per year) vertebrates and is broadly distributed in the Indo-West Pacific, inhabiting coral reef lagoons (Watson and Walker 2004).

Extraordinary cryptic diversity of gobioid paedomorphic genus Schindleria has been evidenced revealed by molecular phylogenetic analysis (Kon et al. 2007). At least 21 cryptic species of Schindleria potentially exist around the Ryukyu and Ogasawara Islands (Japan), and the Palau Islands, based on a molecular phylogenetic analysis (Kon et al. 2011). The first species was described from the Hawaiian Islands as Hemiramphus praematurus by Schindler (1930), who assumed that the species was a larval hemiramphid. The second species was also described by Schindler (1931), also from the Hawaiian Islands, as Hemiramphus pietschmanni. Giltay (1934), who had found a single specimen of $H$. praematurus off New Guinea, concluded that there was no evidence of a close relation to other known hemiramphids, and therefore described a new genus Schindleria for inclusion of the two species, with Schindleria praematura (Schindler, 1930) as the type species by the original designation, within a new family Schindleriidae (see van der Laan et al. 2014: 124). Johnson and Brothers (1983) demonstrated that the family is a member of the suborder Gobioidei. Gill and Mooi (2010) found a close relation of schindleriids to microdesmids. The third species, Schindleria brevipinguis Watson et Walker, 2004, was described off north-eastern Australia (Watson and Walker 2004).

Abu El-Regal and Kon (2008) reported a specimen of Schindleria sp. off Hurghada, Egypt, which they found to be close to Schindleria pietschmanni (Schindler, 1931), thus documenting the presence of this genus in the Red Sea for the first time. The second and the third species of Schindleria described from the Red Sea were Schindleria elongata Fricke et Abu El-Regal, 2017 and Schindleria nigropunctata Fricke et Abu El-Regal, 2017 (Fricke and Abu El-Regal 2017a, 2017b). During his survey on the ichthyoplankton in Hurghada on the Egyptian Red Sea coast, the first author of the present paper collected many specimens representing the family Schindleriidae. Some of these specimens were identified as Schindleria praematura, based on morphological characteristics.

\section{MATERIAL AND METHODS}

Fish specimenswerecollected fromashallowreeflagoon around the Magawish Islands $27^{\circ} 10^{\prime} 02^{\prime \prime} \mathrm{N}, 033^{\circ} 52^{\prime} 27^{\prime \prime} \mathrm{E}$, in Hurghada on the Egyptian Red Sea coast, by the first author, while fishing for larvae of reef fish. Samples were taken by a light trap in September 2016 at 22:00 h. The fish were 
preserved in $70 \%$ ethanol and brought to the laboratory of the Marine Science Department, Port Said University, for examination. Counts, measurements, and description of the body shape follow Leis and Carson-Ewart (2004). A stereomicroscope equipped with an ocular micrometre and camera was used to make counts and measurements and photograph the fish.

\section{RESULTS}

Eight specimens, five of which were female, two were recognized as male, and one which could not be sexed were identified as Schindleria praematura based on morphological characters (Table 1). The identification of the specimens as Schindleria sp. was based on the following combination of the observed characters: transparent and slender body, elongate and smooth gut, elongate urostyle, 13 principal caudal-fin rays, presence of urogenital papilla

Table 1

Morphometric characters of Schindleria praematura collected from the Red Sea

\begin{tabular}{ccccc}
\hline \multirow{2}{*}{$\begin{array}{c}\text { Spec. } \\
\text { No. }\end{array}$} & \multirow{2}{*}{ SL } & \multicolumn{2}{c}{ Fin ray No. } & \multirow{2}{*}{ Sex } \\
\cline { 3 - 4 } & & Dorsal & Anal & \\
\hline 1 & 16.2 & 16 & 10 & Female \\
2 & 14.3 & 17 & 11 & Female \\
3 & 16.6 & 17 & 11 & Male \\
4 & 13.3 & 17 & 11 & Female \\
5 & 10.5 & - & - & $?$ \\
6 & 10.6 & - & - & Female \\
7 & 12.6 & 17 & 11 & Female \\
8 & 11 & - & - & Male \\
\hline
\end{tabular}

Spec. No. $=$ specimen number, $\mathrm{SL}=$ standard length.
(Watson 2004). They then were identified as S. praematura based on the following criteria: Specimens were almost devoid of pigment except for the eyes and one melanophore on the gas bladder and were very elongate and slender with $39(20+19)$ myomeres. Standard length (SL) varied from $10.5 \mathrm{~mm}$ to $16.6 \mathrm{~mm}$. The morphometrics are given in Table 1. The head was small with a short, rounded snout. The mouth was of moderate size and reached the mideye. The teeth were small. The gut was straight, smooth, and elongate, extending to $53 \%$ of the standard length. The urostyle and caudal peduncle were elongate. The small but conspicuous gas bladder was situated within the second two-thirds of the body ( $66 \%$ of SL). The dorsal-fin origin was at myomere 20 and the first anal-fin ray lied under the fourth dorsal-fin ray. The dorsal and anal fins contained 16-17 and 10-11 rays, respectively. The pelvic fins were completely absent. The caudal fin had about five dorsal and five ventral procurrent rays (Fig. 1, Table 2).

\section{DISCUSSION}

Schindleria praematura is confined to Indo-West Pacific coral reefs and is distributed from southern Japan and the South China Sea, south to the Great Barrier Reef (Australia) and Papua New Guinea, and Palau and the Marshall Islands. It has also been reported from Sala y Gómez and Easter Island (Larson and Murdy 2010). The closest area where the species was recorded is Madagascar in the western Indian Ocean (Fig. 2). This is the first record of the species in the Red Sea. It significantly extends the known distribution of this species northward in the Indo-West Pacific.

Together with $S$. elongata, and the species reported by Abu El-Regal and Kon (2008), as well as S. nigropunctata (see Fricke and Abu El-Regal 2017b), there are now four

Comparison between Schindleria praematura and other Schindleria species in the Red Sea

Table 2

\begin{tabular}{|c|c|c|c|c|}
\hline \multirow[b]{2}{*}{ Character } & \multicolumn{4}{|c|}{ Species and reference } \\
\hline & $\begin{array}{l}\text { S. elongata } \\
\text { FA 2017a }\end{array}$ & $\begin{array}{c}\text { S. nigropunctata } \\
\text { FA } 2017 \mathrm{~b}\end{array}$ & $\begin{array}{l}\text { Schindleria sp. } \\
\quad \text { AK } 2008\end{array}$ & $\begin{array}{c}\text { S. praematura } \\
\text { PRS }\end{array}$ \\
\hline Dorsal-fin rays & $13-14$ & 13 & 16 & $16-22$ \\
\hline Anal-fin rays & $10-11$ & $11-12$ & 15 & $10-14$ \\
\hline Position of first anal-fin ray relative to dorsal-fin ray & 2 nd -4 th & 2 nd & 4th & 7 th-11th \\
\hline Teeth & Small & Small & Absent & Small \\
\hline Predorsal length [mm] & $66-70$ & $66-67$ & 60 & 54 \\
\hline Preanal length $[\mathrm{mm}]$ & $66-71$ & $67-68$ & 64 & 53 \\
\hline Head length $[\mathrm{mm}]$ & $17-18$ & $14-15$ & 17 & $13-16$ \\
\hline Eye diameter [mm] & $28-32$ & $14-18$ & 26 & 25 \\
\hline Body depth at pectoral-fin base [mm] & $4-5$ & $5-6$ & 8 & 6 \\
\hline Body depth at anal-fin origin [mm] & $5-7$ & 9 & 11 & 6 \\
\hline Position of gas bladder & $56 \%-60 \% \mathrm{SL}$ & $47 \%-49 \% \mathrm{SL}$ & $46 \% \mathrm{SL}$ & $66 \% \mathrm{SL}$ \\
\hline Pigment & No & Yes & Yes & Yes \\
\hline Distribution & Red Sea & Red Sea & Red Sea & $\begin{array}{l}\text { Indo-West } \\
\text { Pacific, } \\
\text { Red Sea }\end{array}$ \\
\hline
\end{tabular}

FA 2017a = Fricke and Abu El-Regal 2017a, FA 2017b = Fricke and Abu El-Regal 2017b, AK 2008 = Abu El-Regal and Kon 2008, PRS = presently reported study. 


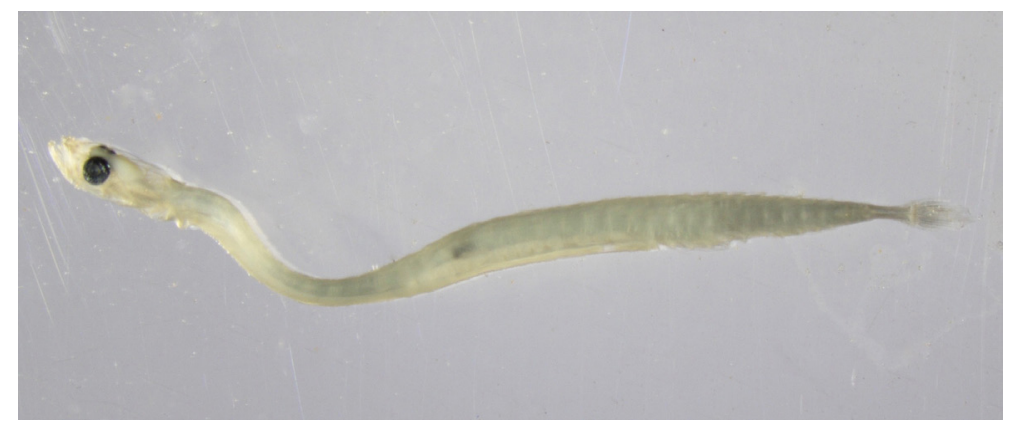

Fig. 1. Male Schindleria praematura (16.6 $\mathrm{mm} \mathrm{SL})$, collected from the Red Sea

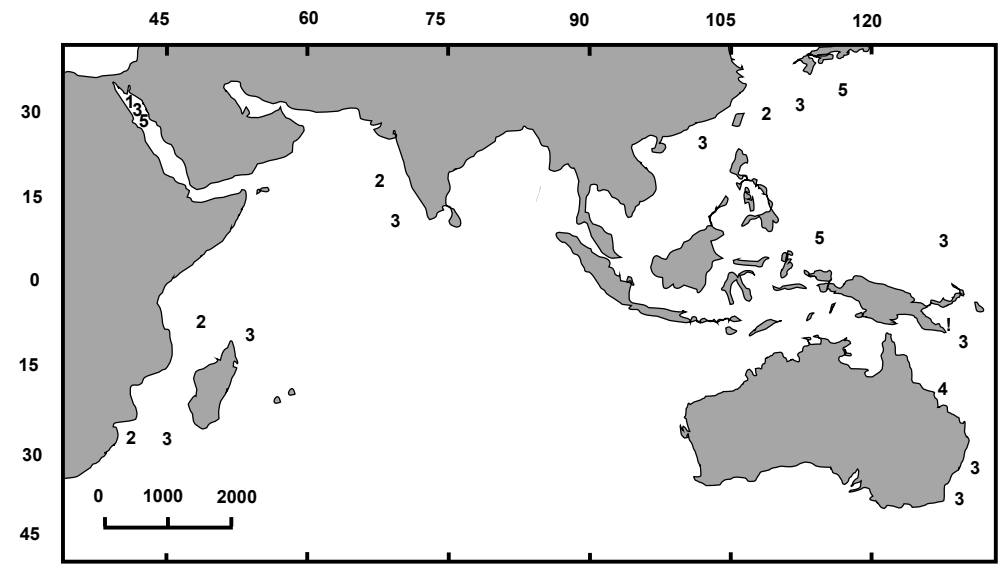

Fig. 2. Distribution of species in the genus Schindleria in the Indo-Pacific (After Fricke and Abu El-Regal 2017b.); $\mathbf{1}=$ Schindleria elongata and $S$. nigropunctata $; \mathbf{2}=$ Schindleria pietschmanni; $\mathbf{3}=$ Schindleria praematura $\mathbf{4}=$ Schindleria brevipinguis; $\mathbf{5}$ = Schindleria spp. (not assigned to any nominal species)

species of schindleriids found sympatrically in the Red Sea near Hurghada, Egypt. The Red Sea is known for its richness in ichthyofauna with more than 1100 species in 154 families (Golani and Bogorodsky 2010). This report of Schindleria praematura increases the fish diversity in the Red Sea and raises the number of species in family Schindleriidae to four. This finding could also provide the basis for some interesting zoogeographic studies of the family.

\section{ACKNOWLEDGEMENTS}

The authors would like to thank the Science and Technology Development Funding (STDF) of the Ministry of Scientific Research, Egypt for funding this work through the project "Utilization of the ichthyoplankton for the management of the Red Sea Fisheries". We would like to thank Vanessa Robitzch, Institute of Environmental Science and Evolution, Austral University of Chile, for her invaluable help in finalizing the distribution map of the species.

\section{REFERENCES}

Abu El-Regal M., Kon T. 2008. First record of the paedomorphic fish Schindleria (Gobioidei, Schindleriidae) from the Red Sea. Journal of Fish Biology 72 (6): 1539-1543. DOI: 10.1111/j.10958649.2008.01811.x
Fricke R., Abu El-Regal M. 2017a. Schindleria elongata, a new species of paedomorphic gobioid from the Red Sea (Teleostei: Schindleriidae). Journal of Fish Biology 90 (5): 1883-1890. DOI: 10.1111/ jfb. 13280

Fricke R., Abu El-Regal M. 2017b. Schindleria nigropunctata, a new species of paedomorphic gobioid fish from the Red Sea (Teleostei: Schindleriidae). Marine Biodiversity. DOI: 10.1007/s12526-0170831-z

Johnson G.D., Brothers E.B. 1993. Schindleria: A paedomorphic goby (Teleostei: Gobioidei). Bulletin of Marine Science 52 (1): 441-471.

Gill A.C., Mooi R.D. 2010. Character evidence for the monophyly of the Microdesminae, with comments on relationships to Schindleria (Teleostei: Gobioidei: Gobiidae). Zootaxa 2442 (1): 51-59. DOI: 10.11646/ zootaxa.2442.1.4

Giltay L. 1934. Notes ichthyologiques VIII. - Les larves de Schindler sont elles des Hemirhamphidae? Bulletin du Musée Royal d'Histoire Naturelle de Belgique 10 (13): 1-10.

Golani D., Bogorodsky S. 2010. The fishes of the Red Sea-Reappraisal and updated checklist. Zootaxa 2463: 1-135. 
Kon T., Yoshino T., Mukai T., Nishida M. 2007. DNA Schindler O. 1931. Ein neuer Hemirhamphus aus dem sequences identify numerous cryptic species of the vertebrate: A lesson from the gobioid fish Schindleria. Molecular Phylogenetics and Evolution 44 (1): 53-62. DOI: 10.1016/j.ympev.2006.12.007

Kon T., Yoshino T., Nishida M. 2011. Cryptic species of the gobioid paedomorphic genus Schindleria from Palau, western Pacific Ocean. Ichthyological Research 58 (1): 62-66. DOI: 10.1007/s10228-010-0178-y

Larson H.K., Murdy E. 2010. Schindleria praematura (errata version published in 2017). The IUCN Red List of Threatened Species 2010: e.T154836A115240357. [Downloaded on 19 January 2019.] DOI: 10.2305/ IUCN.UK.2010-4.RLTS.T154836A4646866.en

Leis J.M., Carson-Ewart B.M. (eds.) 2004. The larvae of Indo-Pacific coastal fishes. 2nd edn. Brill, Leiden, the Netherlands.

Schindler O. 1930. Ein neuer Hemirhamphus aus dem Pazifischen Ozean. Anzeiger der Akademie der Wissenschaften in Wien 67 (9): 79-80.

Pazifischen Ozean. Anzeiger der Akademie der Wissenschaften in Wien 68 (1): 2-3.

van der Laan R., Eschmeyer W.N., Fricke R. 2014. Family-group names of recent fishes. Zootaxa $\mathbf{3 8 8 2}$ (1): 1-230. DOI: 10.11646/zootaxa.3882.1.1

Watson W. 2004. Schindleriidae (Schindler's fishes). P. 633. In: Leis J.M., Carson-Ewart B.M. (eds.) The larvae of Indo-Pacific coastal fishes. 2nd edn. Brill, Leiden, the Netherlands.

Watson W., Walker H.J.jr. 2004. The world's smallest vertebrate, Schindleria brevipinguis, a new paedomorphic species in the family Schindleriidae (Perciformes: Gobioidei). Records of the Australian Museum 56 (2): 139-142. DOI: 10.3853/j.00671975.56.2004.1429

Received: 21 April 2018 Accepted: 23 September 2018 Published electronically: 15 March 2019 